\title{
Studies on the Interaction Between Humic Substances and Conducting Polymers for Sensor Application
}

\author{
Everaldo C. Venancio ${ }^{a}$, Nelson Consolin Filho ${ }^{a, b}$, Carlos J. L. Constantino ${ }^{c}$, Ladislau Martin-Neto ${ }^{a}$ \\ and Luiz H. C. Mattoso ${ }^{*, a}$ \\ ${ }^{a}$ Embrapa Instrumentação Agropecuária, CNPDIA/Embrapa, CP 741, 13560-970 São Carlos - SP, Brazil \\ ${ }^{b}$ Ciência e Engenharia de Materiais, IQSC/IFSC/EESC, Universidade de São Paulo, 13560-970 São Carlos - SP, Brazil \\ ${ }^{c}$ Departamento de Física, Química e Biologia, FCT-Universidade Estadual Paulista, \\ 19060-900 Presidente Prudente -SP, Brazil
}

\begin{abstract}
Neste trabalho, foi investigada a interação entre substâncias húmicas e um polímero condutor (poli-(o-etoxianilina) - POEA), ambos em solução e filmes automontados. Os resultados mostram que as substâncias húmicas dopam a POEA por protonação, isto é evidenciado por espectroscopia UV-Vis e Raman. Os estudos de microscopia de força atômica (AFM) em filmes automontados mostram haver um aumento na rugosidade do filme polimérico quando este é exposto a substâncias húmicas (ácidos húmico e fúlvico), o que evidencia a existência de interação entre a POEA e as substâncias húmicas. Esta mudança na morfologia é reversível com a lavagem dos filmes com água, em concordância com as medidas elétricas, possibilitando a aplicação em sensores. Um sistema sensor formado por um arranjo de diferentes unidades sensoriais foi capaz de distinguir substâncias húmicas em solução aquosa, como é mostrado pela análise multivariada (análise da componente principal), o que é importante para controle da qualidade de água e solo.
\end{abstract}

The interaction between humic substances and poly(o-ethoxyaniline) (POEA), a conducting polymer, was investigated for both solution and self-assembled films. The results have shown that the humic substances induce a doping of POEA by protonation, as indicated by UV-Vis and Raman spectroscopies. The atomic force microscopy (AFM) studies on the self-assembled films have shown that the average roughness of the polymer film has increased after exposing it to humic substances (fulvic and humic acids), consistent with the interaction between POEA and humic substances. However, this change in morphology is reversible by washing the films with water in agreement with the electrical data allowing using this system in sensor applications. Here, the sensor formed by an array of different sensing units was able to detect and distinguish humic substances in aqueous solution, as shown by multivariate analysis (principal component analysis). The motivation to detect humic substance comes due to its importance in terms of quality control of water or soil.

Keywords: poly(o-ethoxyaniline), humic substances, sensors

\section{Introduction}

Polyaniline (PANI) and its derivatives are conducting polymers, which can be doped by protonic acid leading to great increase in the electrical conductivity and other related properties. These properties can be also further changed by the interaction with other compounds, which influence the structure, morphology or doping features of the polymer. ${ }^{1-6}$ In the case of PANI derivatives, e.g. $\operatorname{poly}(o-$ ethoxyaniline) (POEA), it has been shown the possibility

*e-mail: mattoso@cnpdia.embrapa.br of complex formation in solution, which may improve some properties of the conducting polymer, such as to extend the doping state up to higher pHs. ${ }^{3,4}$

Humic substances are natural compounds that contain in their structures different chemical functional groups. ${ }^{7-8}$ The acid properties of these humic substances depend on the content of the acid groups, phenol and carboxylic groups, allowing to separate the humic substances in two main groups: humic acids ${ }^{7}$ and fulvic acids. ${ }^{89}$ Usually, fulvic acid is the strongest and it is soluble in all pHs. Humic acids are not soluble in $\mathrm{pH}$ lower than 2 and this property is used to separate them from the fulvic acids. ${ }^{8}$ It 
is well known that humic substances play an important role on water quality determination, as well as on the transport of nutrients in the soil and on the interaction with many different compounds such as heavy metal ions and pesticides. $^{7-11}$ Therefore, the investigation on the interaction between humic substances and POEA is quite important since it might allow using this polymer as a transducer in a composite system for sensor applications. ${ }^{12-14}$

In this work the interaction between humic substances, fulvic and humic acids, and POEA was studied using UVVis absorption and Raman scattering spectroscopies and atomic force microscopy (AFM). The measurements were carried out using both solution and polymer films deposited by self-assembly (SA) technique. ${ }^{3,4}$ The interaction concept was applied in a sensing array containing POEA deposited on interdigitated microelectrodes using capacitance measurements.

\section{Experimental}

The POEA was chemically synthesized using ammonium peroxydisulfate, $1.0 \mathrm{~mol} \mathrm{~L}^{-1}$ hydrochloric acid and excess of monomer according to the method described in the literature. ${ }^{15}$ The humic substances used were bought from Aldrich (humic acid-1, Aldrich), and extracted in our laboratory (fulvic acid and humic acid-2), according to the method described elsewhere. ${ }^{7,8}$ The substrate used to obtain the SA film of POEA was Suprazil ${ }^{\circledR}$ quartz previously washed according to the method described by Kern. ${ }^{16}$ The aqueous solutions of POEA and humic substances were prepared using ultrapure water from a Milli-Q system (MilliPore). The other chemicals were used as received. The concentrations of the humic substance solutions were 5,10 and $30 \mathrm{mg} \mathrm{L}^{-1}$. The solution $\mathrm{pHs}$ were controlled using either hydrochloric acid solution ( $\mathrm{pH}$ 5.0) or phosphate buffer solution ( $\mathrm{pH}$ 5.4). The o-ethoxyaniline (Aldrich) monomer was distilled in the presence of powder zinc at low pressure. The POEA SA films were prepared as described elsewhere. ${ }^{4}$

The UV-Vis experiments were carried out using a Shimadzu spectrophotometer, model UV-1601PC, in a wavelength range of 1100 to $190 \mathrm{~nm}$. The AFM studies were carried out using a Nanoscope IIIA atomic force microscope (Digital Instruments) operating in the tapping mode. The cantilever tips used were single beam rectangular shaped, tapping mode etched silicon using a spring constant of $70 \mathrm{Nm}^{-1}$ and a resonance frequency of $280 \mathrm{kHz}$. The Raman spectra were recorded with $633 \mathrm{~nm}$ laser line (He-Ne laser, Spectra Physics, mod 127) using a Renishaw Raman Image (system 3000) equipped with an Olympus metallurgic microscope and a CCD detector.
The sensing units were prepared using the SA technique as described elsewhere. ${ }^{4}$ In the SA technique was used time scale as following: 1) 1 step of 1 minute (POEA-SA1);2) 1 step of 3 min (POEA-SA2); 3) 1 step of 10 min (POEASA3). These experiments were carried out at $\mathrm{pH} 3.0(\mathrm{HCl})$ using $1 \times 10^{-3} \mathrm{~mol} \mathrm{~L}^{-1}$ POEA aqueous solution (Table 1). Electrochemical experiments were carried out using a frequency Responses analyzer AUTOLAB Eco Chemie PGSTAT20 driving by the Eco Chemie GPES software. The signal amplitude was $10 \mathrm{mV}_{\mathrm{rms}}$. The frequency range was between $50 \mathrm{kHz}$ and $10 \mathrm{~Hz}$. A Pirex ${ }^{\circledR}$ glass backer was used as electrochemical cell under air atmosphere.

\section{Results and Discussion}

Spectroscopy investigation of the interaction between POEA and humic substances

The interaction between POEA and humic substances in aqueous solution was studied by UV-Vis and Raman spectroscopic techniques. It can be seen in Figure 1 that the polaronic absorption band maximum of the polymer was shifted to higher wavelengths with the increase of the humic substance concentration into the POEA solution from 0 to $30 \mathrm{mg} \mathrm{L}^{-1}$. According to the literature ${ }^{17}$ this shift in the polaronic band is attributed to a doping effect by protonation. Therefore, an interaction of the humic substances with the POEA polymer backbone could be responsible by the POEA doping since the humic substances have in their structure many chemical functional groups, ${ }^{7-9}$ such as carboxylic and phenol acid groups. It could be thought that the acid groups could act changing the solution $\mathrm{pH}$, due to the humic substance addition. However, the results have shown that the maximum of the POEA polaronic band was shifted to higher wavelength even in the presence of the phosphate buffer (fixed $\mathrm{pH}$ ), which corroborates with the fact that the humic substances must induce primary doping of POEA by due to changes on the Donnan equilibrium caused by complexation of POEA with humic substances, as it has been observed for others systems. ${ }^{4}$ A similar effect was observed for SA films of POEA immersed into humic substance solutions, carried out by AFM as it will be shown later. It has been previously observed that POEA possess strong interaction with lignin derivatives which present similar chemical structures to humic substances. ${ }^{21,24}$ Also this observation is consistent with a proton transfer reaction between humic acids and the herbicide atrazine (6-chloro- $N^{2}$-ethyl- $N^{4}$-isopropyl1,3,5-triazine-2,4-diamine), as detected by FTIR. ${ }^{25}$

Figure 2 presents the Raman spectra recorded with the $633 \mathrm{~nm}$ laser line for (A) fulvic acid solution $5 \mathrm{mg} \mathrm{L}^{-1}(\mathrm{pH}$ 

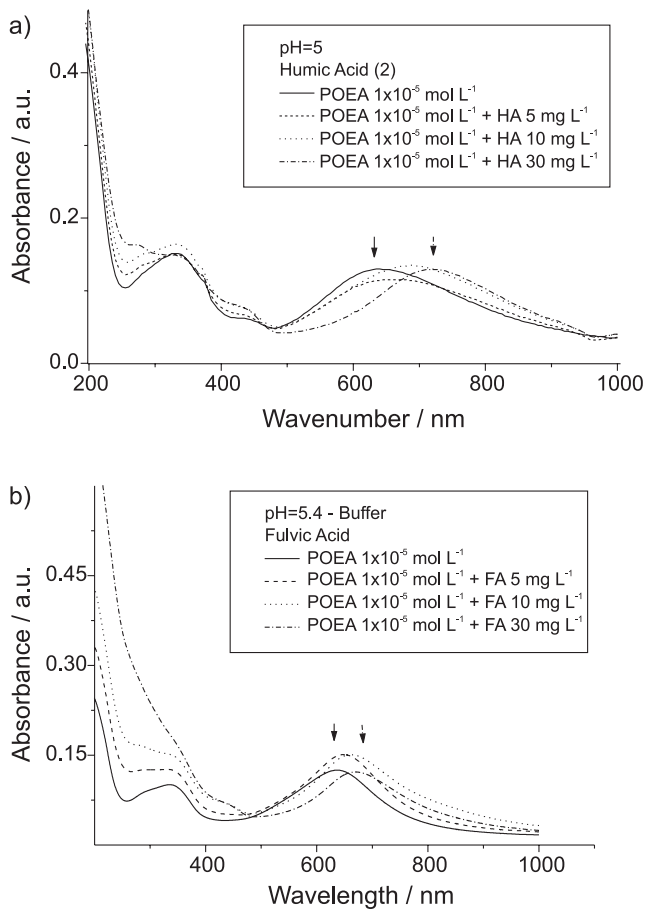

Figure 1. UV-Vis spectra of $1 \times 10^{-5} \mathrm{~mol} \mathrm{~L}^{-1}$ POEA dissolved in aqueous solution containing different humic acid concentrations $(5,10 \mathrm{e}$ $30 \mathrm{mg} \mathrm{L}^{-1}$ ): (a) humic acid-2 at $\mathrm{pH} 5.0(\mathrm{HCl})$ and (b) fulvic acid in phosphate buffer at $\mathrm{pH} 5.4$.

5.0), (B) aqueous solution ( $\mathrm{pH} 5.0$ ) of POEA $+30 \mathrm{mg} \mathrm{L}^{-1}$ fulvic acid, (C) aqueous solution (pH 5.0) of POEA +10 $\mathrm{mg} \mathrm{L}^{-1}$ fulvic acid, (D) aqueous solution (pH 5.0) of POEA $+5 \mathrm{mg} \mathrm{L}^{-1}$ fulvic acid and (E) POEA powder doped in $\mathrm{HCl}$ $1 \mathrm{~mol} \mathrm{~L}^{-1}$. By comparison with the spectrum of primary doped POEA using $\mathrm{HCl}$ (protonation), ${ }^{18}$ it can be extracted from Figure 2 that the spectra of the mixed solutions containing POEA + fulvic acid (B, C and D) show that the POEA is doped as indicated by the characteristic band around $1340 \mathrm{~cm}^{-1}\left(1327 \mathrm{~cm}^{-1}\right.$ in the case of spectrum E) assigned to $\mathrm{C}-\mathrm{N}^{+}$stretching of radical cation (polaron) supporting what was observed by UV-Vis spectroscopy. Other bands related to primary doping are seen for the mixed solutions where the quinoid and semiquinoid bands are greater due to the resonance with the $633 \mathrm{~nm}$ laser line such as $1585 \mathrm{~cm}^{-1}$ assigned to the $\mathrm{C}=\mathrm{C}$ stretching and 1620 $\mathrm{cm}^{-1}$ attributed to C-C stretching, ${ }^{19}$ besides the band at $1507 \mathrm{~cm}^{-1}$ assigned to $\mathrm{N}-\mathrm{H}$ bending.

\section{AFM analysis of the interaction between POEA films and humic substances}

Figure 3 presents the AFM images $(1 \mu \mathrm{m} \times 1 \mu \mathrm{m})$ of SA POEA films before and after interactions with the humic substances. A globular morphology was observed for all POEA, which is consistent with other works in the

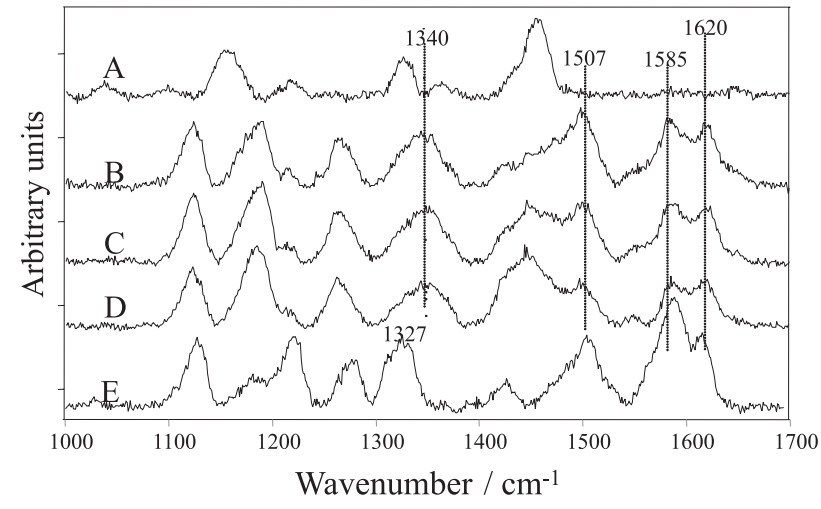

Figure 2. Raman spectra recorded with the $633 \mathrm{~nm}$ laser line for aqueous solution at $\mathrm{pH} 5.0$ containing: (A) fulvic acid $5 \mathrm{mg} \mathrm{L}^{-1}$, (B) POEA + $30 \mathrm{mg} \mathrm{L}^{-1}$ fulvic acid, (C) POEA + $10 \mathrm{mg} \mathrm{L}^{-1}$ fulvic acid, (D) POEA $+5 \mathrm{mg} \mathrm{L}^{-1}$ fulvic acid, (E) POEA powder doped with $\mathrm{HCl}$ $\left(1 \mathrm{~mol} \mathrm{~L} \mathrm{~L}^{-1}\right)$.

literature. ${ }^{21}$ However, the globule size has increased significantly when the SA POEA films were immersed into buffer solution containing fulvic and humic acids, respectively. The increase in the globule size is due to the complexation of POEA with the humic substances wich are, relatively big structures and then result in globules with higher volume than POEA itself. Ferreira et al. ${ }^{23}$ studied the interaction between humic acid and basal-plane surfaces of fleshly cleaved mica by AFM and showed the formation of globular particles of humic acid in the order of $40-50 \mathrm{~nm}$ in diameter, which is about the same as that obtained in the present study (40-70 nm).

Figure 4 shows the section analysis of the AFM images of the SA POEA films after exposing to humic substances. One can observe distinct features for the shape and size of the globular structure. For instance, it can be seen the formation of globular agglomerates after exposing the POEA monolayer to humic acid-1. It can be seen comparing Figures 3 and 4 that the globules are bigger for POEA immersed into phosphate buffer solution than those obtained for the POEA into $\mathrm{HCl}$ aqueous solution. This is probably due to the high sensibility of the doping level at POEA, which has a strong variation as a function of $\mathrm{pH}$. Thus, the interchain interaction at $\mathrm{pH} 5.4$ might be higher than that at $\mathrm{pH} 5.0$ leading the system to have a structure with bigger globules than those at $\mathrm{pH} 5.0$ consistently with the data obtained by Paterno et al. ${ }^{4}$

Figure 5 presents the variation of the average roughness of POEA monolayer upon different cycles of exposure to humic substances (namely POEA+FA and POEA+HA, where $\mathrm{FA}=$ fulvic acid and $\mathrm{HA}=$ humic acid) as well as after they were washed again with phosphate buffer aqueous solution to check the reversibility of the system. It must be point out that the average roughness has increased from 0.55 to $1.27 \mathrm{~nm}$ as well as the globules present at the surface 

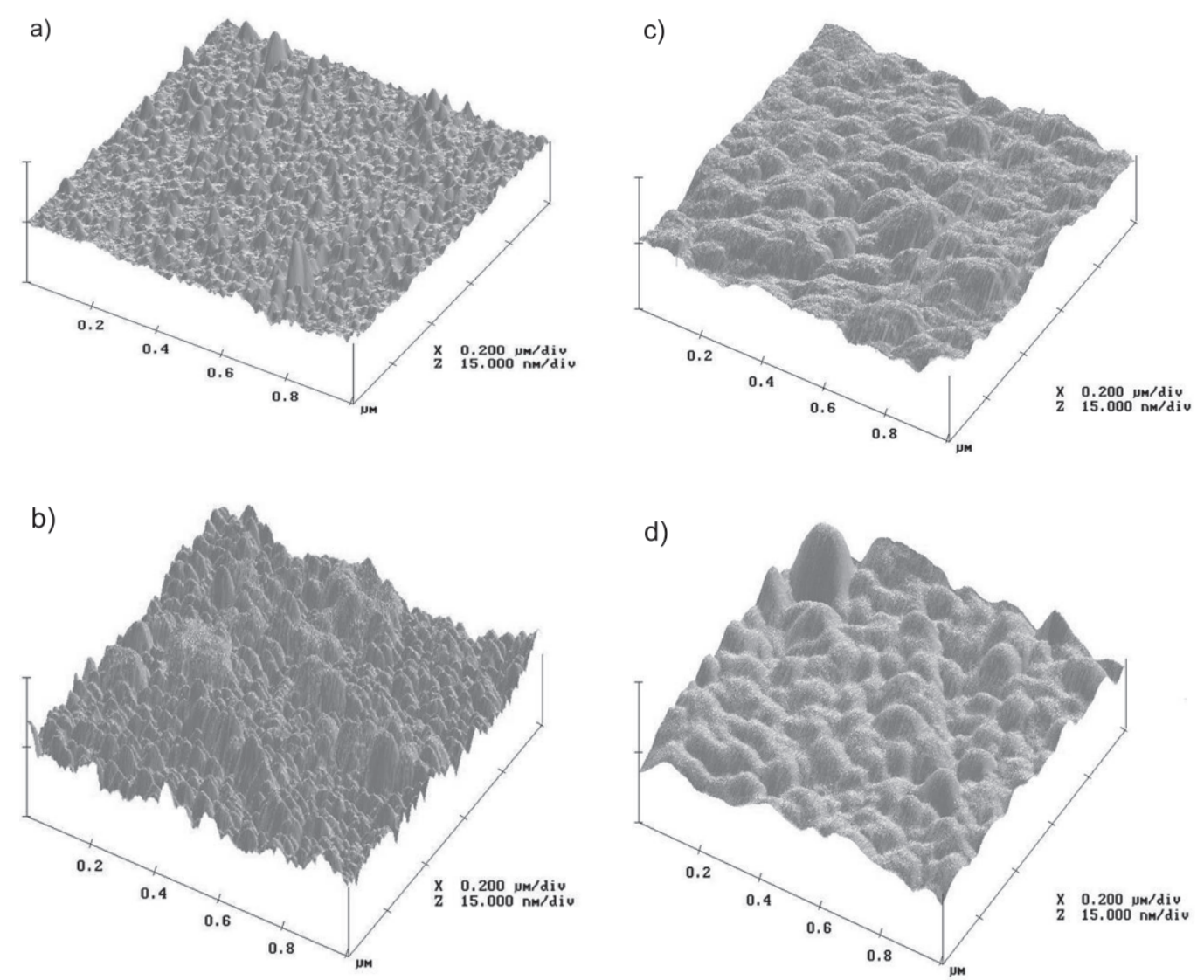

Figure 3. AFM images $(1 \mu \mathrm{m} \times 1 \mu \mathrm{m}$ ) of SA monolayer of POEA after immersion into (a) $\mathrm{HCl}$ aqueous solution at $\mathrm{pH} 5.0$ (HCl), (b) phosphate buffer solution at $\mathrm{pH} 5.4$, (c) phosphate buffer solution at $\mathrm{pH} 5.4$ containing $30 \mathrm{mg} \mathrm{L}^{-1}$ of fulvic acid and (d) phosphate buffer solution at $\mathrm{pH} 5.4$ containing $30 \mathrm{mg} \mathrm{L}^{-1}$ of humic acid-1. $\mathrm{z}=15 \mathrm{~nm}$.
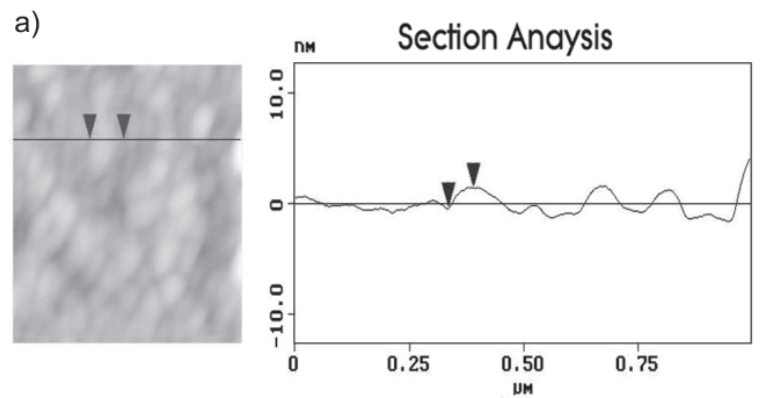

b)
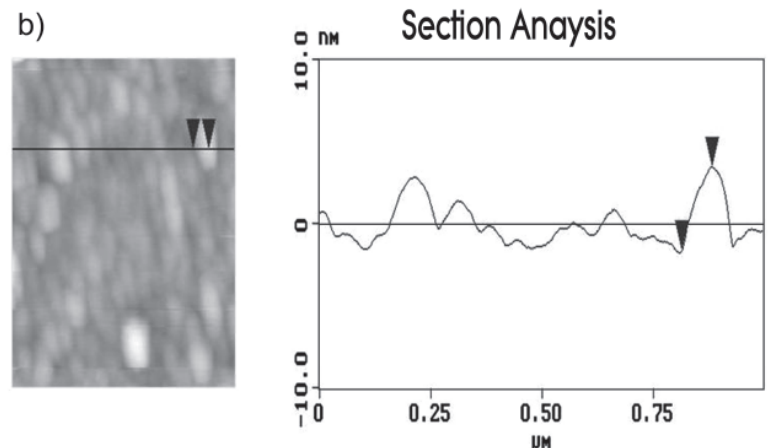

Figure 4. Section analysis of the AFM images of SA monolayer of POEA after immersion into (a) phosphate buffer solution at $\mathrm{pH} 5.4$ containing $30 \mathrm{mg} \mathrm{L}^{-1}$ of fulvic acid and (b) phosphate buffer solution at $\mathrm{pH} 5.4$ containing $30 \mathrm{mg} \mathrm{L}^{-1}$ of humic acid-1. Magnification: $1 \mathrm{x} 1 \mu \mathrm{m}^{2}$. after the deposition of the SA POEA monolayer on the substrate, which could be expected since the morphology of the POEA layer is influenced by the substrate morphology. ${ }^{19}$ The average roughness of the POEA monolayer has changed from 1.17 to 1.58 after dipped into fulvic solution and to $1.61 \mathrm{~nm}$ after dipped into humic acid-1 solution. These average roughness values were measured in different regions on the SA POEA monolayer for an area of $1 \times 1 \mu \mathrm{m}^{2}$. Riul Jr. et al. ${ }^{20}$ have shown in a recent study that the average roughness of LangmuirBlodgett (LB) films has changed in a different way when in the presence of different analytes such as sodium chloride, hydrochloric acid and glucose. All the roughness and globule size variations corroborate the interaction between the POEA and the humic substance molecules.

It is important to point out that neither roughness nor morphology variation was observed for the 3-bilayer of POEA and sulfonated lignin (SL) forming SA film when the last layer is SL. This supports the fact that the POEA must be responsible for the interaction with the humic substances. A very important observation from these results is that the changes in roughness and in surface morphology 


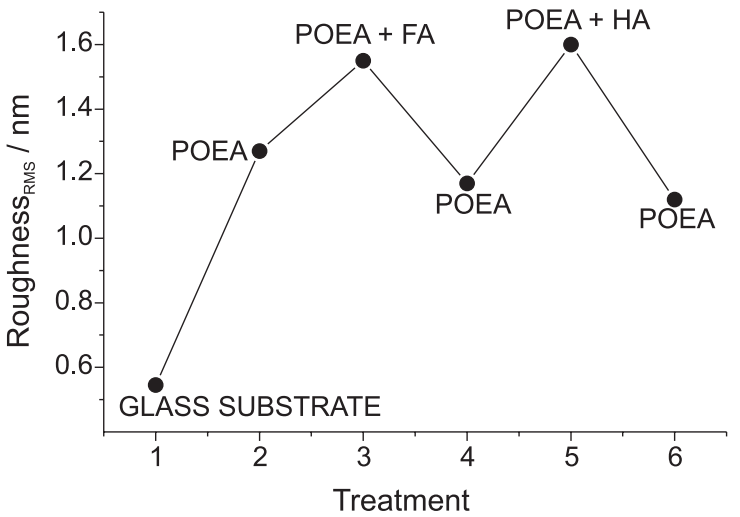

Figure 5. Average roughness $\left(\mathrm{R}_{\mathrm{rms}}\right)$ variations for $\mathrm{SA}$ monolayer of POEA film exposed to humic substances (POEA+AF; POEA+AH) and washing cycles, as indicated. The concentration for fulvic acid and humic acid-1 was $30 \mathrm{mg} \mathrm{L}^{-1}$. The solution $\mathrm{pH}$ was maintained by a phosphate buffer solution ( $\mathrm{pH}$ 5.4).

are reversible indicating that the humic substances could be washed out of the POEA surface, which allowed the application of these films as sensor, as it will be shown later. This variation in microscopic properties might have a strong influence in the electrical properties of the POEA SA films, such as capacitive and resistive properties.

\section{Sensor application}

The construction of a sensor for humic substances using POEA was made as an application based on the reversible interaction shown previously. The sensor is formed by an array of sensing units whose interdigitated microelectrode ${ }^{26}$ were covered by thin POEA films using the SA technique. ${ }^{4}$ The sensors evaluate the changes in the capacitive and conductive properties of the polymeric film based on the impedance spectroscopy ${ }^{26-27}$ technique. The electrochemical impedance spectroscopy measurements were carried out at the open circuit potential. The amplitude of the perturbation signal was changed from 10 to $50 \mathrm{mV}_{\text {rms }}$ and it has shown no difference on the impedance results in this range.

The interdigitated array of sensing units forming the sensor is given in Table 1. The effect of the dopant anion on the sensing unit was studied by changing the composition of the solution containing the POEA for the fabrication of SA film. Hydrochloric acid $(\mathrm{HCl})$, camphorsulfonic acid (CSA) and toluenesulfonic acid (TSA) were used for that. The description of each sensing unit is in Table 1. Preliminary studies were carried out at pH 3.0 but at this condition a problem became important. In this $\mathrm{pH}$ the fulvic acids are soluble but the humic acids have low solubility. Therefore, the experiments were carried out at $\mathrm{pH}^{3} 5.0, \mathrm{pH} 5.0(\mathrm{HCl})$ and $\mathrm{pH} 5.4\left(0.2 \mathrm{~mol} \mathrm{~L}^{-1}\right.$ phosphate buffer solution), respectively, to eliminate the solubility effects.

Table 1. Sensing units used in the interdigitated sensor array to analyze the humic substances. SA $=$ Self-Assembled ultrathin films

\begin{tabular}{cc}
\hline Sensing Unit & Type of Material \\
\hline 1 & POEA-SA1 \\
2 & POEA-SA2 \\
3 & POEA-SA3 \\
4 & POEA+SL-AS \\
\hline
\end{tabular}

Figure 6 presents the results at $1 \mathrm{kHz}$ obtained for the humic acid-1 (Figure 6a) and fulvic acid (Figure 6b) detected in $0.2 \mathrm{~mol} \mathrm{~L}^{-1}$ phosphate buffer solution at $\mathrm{pH}$ 5.4 , respectively. This study was carried out to check both the buffer effect and the ability to distinguish the two humic substances by the sensor. This result shows the different capacitance values for two different humic substances at the same aqueous medium and concentration. The capacitance response of the sensor array represents a kind of fingerprint for each humic substance allowing distinguishing humic and fulvic substances.
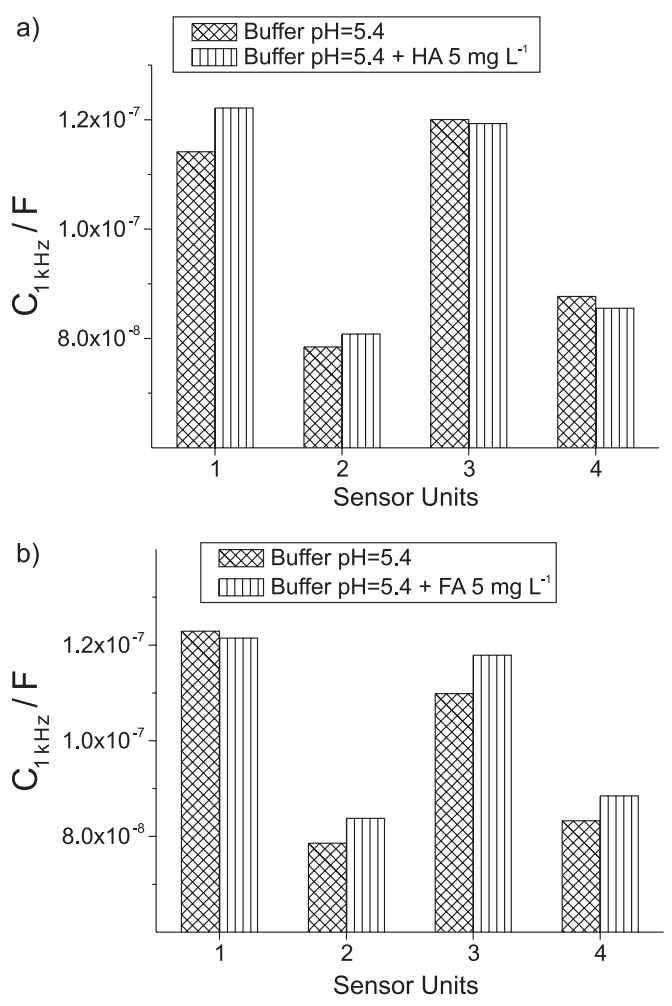

Figure 6. Sensor capacitance values obtained at $1 \mathrm{kHz}$ for $0.2 \mathrm{~mol} \mathrm{~L}^{-1}$ phosphate buffer aqueous solution at $\mathrm{pH} 5.4$ containing (a) no humic substance, (b) $10 \mathrm{mg} \mathrm{L}^{-1}$ fulvic acid and (c) $10 \mathrm{mg} \mathrm{L}^{-1}$ humic acid-1, respectively.

Figure 7 presents the multivariate analysis results showing that the sensor is able to distinguish among Milli- 
Q water, aqueous solution at $\mathrm{pH} 5.0(\mathrm{HCl})$, phosphate buffer aqueous solution at $\mathrm{pH} 5.4$ and the aqueous solutions containing either humic acids or fulvic acid. PC1 (96.91\%) (Figure 7a) information about the system can separate it in two major groups, one at $\mathrm{pH} 5.0(\mathrm{HCl})$ and other at $\mathrm{pH} 5.4$ (buffer). In Figure 7b, PC1 (99.5\%) can further distinguish between the buffered systems with and without humic substance. It also shows the ability of the sensor array in distinguishing between different humic substances, i.e., fulvic and humic acids. This different sensor response for humic and fulvic acids might be related to differences in their acidity, ${ }^{26,27}$ which is also an important factor for characterizing these substances. These results are very promising and it will be extended to humic substances with different properties and from different regions in the near future.
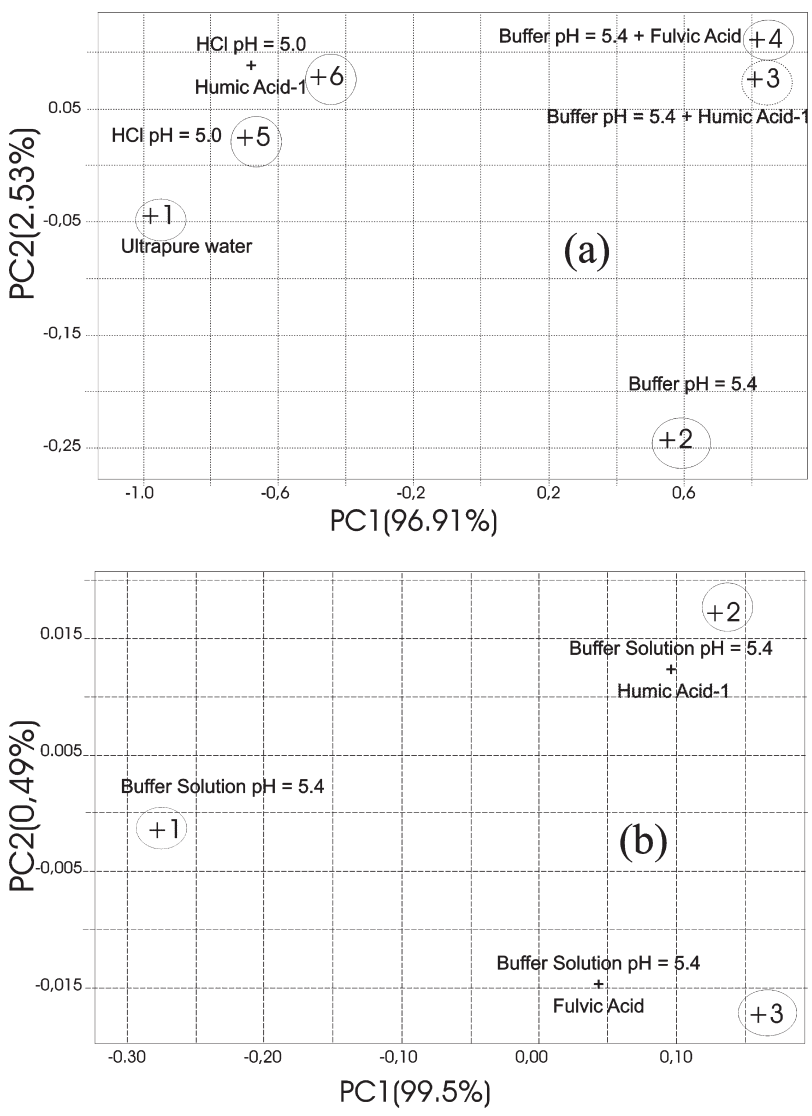

Figure 7. Multivariate analysis for the sensor immersed into Milli-Q water, aqueous solution at $\mathrm{pH} 5.0(\mathrm{HCl})$, phosphate buffer aqueous solution at $\mathrm{pH} 5.4$ and the respective aqueous solutions containing either humic acids or fulvic acid. The analysis was carried out using the 4 sensing units presented in Table 1 .

\section{Conclusions}

The results obtained in this work have indicated an interaction between POEA and humic substances. The UVVis spectra from POEA aqueous solution have shown a shift in the POEA polaronic band to higher wavelength indicating an increase of the doping level of POEA due to the action of the humic substances, which is supported by Raman spectroscopy, even for a constant pH. A POEA/ humic substance complex, in which the carboxylic and phenolic acid groups of the humic substance induce a primary doping by protonation of the imine groups of the POEA, might be probably forming. The AFM studies have shown reversible changes for both surface morphology and average roughness of the POEA self-assembled film upon exposure to aqueous humic substance solutions and washing steps. The great performance of these POEA selfassembled films allowed the development of a sensing array capable of detecting and distinguishing humic substances (fulvic and humic acids) in aqueous solutions.

\section{Aknowledgments}

The financial support given by FAPESP (fellowships to E.C.V., project 00/00586-5; N.C.F., project 02/07724-0) and $\mathrm{CNPq}$ is gratefully acknowledged. We are also indebted to Prof. Dra. Marcia L. A. Temperini (IQ/USP) and Prof. Dr. Ricardo Zanatta (IFSC/USP) for the use of Renishaw micro-Raman facilities.

\section{References}

1. MacDiarmid, A.G.; Epstein, A.J.; Synth. Met. 1994, 65, 103.

2. Santos Jr., J.R.; Malmonge, J.A.; Silva, A.J.G.C.; Motheo, A.J.; Mascarenhas, Y.P.; Mattoso, L.H.C.; Synth. Met. 1995, 69, 141.

3. Paterno, L.G.; Mattoso, L.H.C.; Oliveira, O.N. Jr.; Quim. Nova 2001, 24, 228.

4. Paterno, L.G.; Mattoso, L.H.C.; Polymer 2001, 42, 5239; Constantino, C. J. L.; Oliveira Jr., O. N.; Colloids Surf. B: Biointerfaces 2002, 23, 257.

5. Park, S-M.; Electrochemistry of p-Conjugated Polymers, $3^{\text {th }}$ ed., Wiley: New York, 1997.

6. Angelopoulos, M.; Dipietro, R.; Zheng, W.G.; MacDiarmid, A.G.; Epstein, A.J.; Synth. Met. 1997, 84, 35.

7. MacCarthy, P.; Clapp, C.E.; Malcolm, R.L.; Bloom, P.R.; Substances in Soil and Crop Science: Selected Readings, American Society of Agronomy, Inc.: Madison, WI, EUA, 1990.

8. Northcott, G.L.; Jones, K.C.; Environ. Pollution 2000, 108,19.

9. Novotny, F.J.; Eischen, J.M.; Rice J.A.; Anal. Chim. Acta 1999, 392, 319.

10. Martin-Neto, L.; Sposito, G.; Environ. Sci. Technol. 1994, 28, 1867.

11. Pérez, M. G.; Martin-Neto, L.; Saab, S. C.; Novotny, E. H.; Milori, D. M. B. P.; Bagnato, V. S.; Colnago, L. A.; Melo, W. J.; Knicker, H.; Geoderma 2004, 118, 181. 
12. Riul Jr., A.; Mattoso, L.H.C.; Taylor, D.M.; Mello, S.V.; Venancio, E.C.; Br. PI 0103502-9 2002.

13. Venancio, E.C.; Mattoso, L.H.C.; Martin-Neto, L.; Fonseca, F.J.; Mello, S.V.; Riul Jr., A.; Br. PI 0200409-7 2002.

14. Mattoso, L.H.C.; Venancio, E.C.; Martin-Neto, L.; Fonseca, F.J.; Taylor, D.M.; Mello, S.V.; Riul Jr., A.; US pat., Pending Patent, 2002.

15. Mattoso, L.H.C.; Manohar, S.K.; MacDiarmid, A.G.; Epstein, A.J.; J. Polym. Sci.: Part A: Polym. Chem. 1995, 33, 1227.

16. Kern, W.; Semicond. Int. 1984,94.

17. Ram, M.K.; Maccioni, E.; Nicolini, C.; Thin Solid Films 1997, 303, 27.

18. Piza, M.A.; Constantino, C.J.L.; Venancio, E.C.; Mattoso, L.H.C.; Polymer 2003, 44, 5663.

19. Venancio, E.C.; Costa, C.; Machado, S.A.S.; Motheo, A.J.; Electrochem. Communic. 2001, 3/4, 229.

20. Riul Jr., A.; Venancio, E.C.; Hermann, P.S.P.; Mattoso, L.H.C.; Acta Microscopica 2001, 10, Supplement 1,162.

21. Ram, M.K.; Adami, M.; Sartore, M.; Salerno, M.; Paddeu, S.; Nicolini, C.; Synth. Met. 1999, 100, 249.

22. Furukawa, Y.; Ueda, F.; Hyodo, Y.; Harada, I.; Nakajima, T.; Kawagoe, T.; Macromol. 1998, 21, 1297.
23. Ferreira, J.A.; Osiro, D.; Herrmann, P.S.P.; Martin-Neto, L.; Acta Microscopica 2001, 10, Supplement 1, 43.

24. Vikki, T.; Pietilä, L-O.; Österholm, H.; Ahjopalo, L.; Takala, A.; Toivo, A.; Levon, K.; Pessiniemi, P.; Ikkala, O.; Macromol. 1996, 29,2945.

25. Sposito, G; Martin-Neto, L.; Yang, A.; J. Environ. Quality 1996, 25, 1203.

26. Fiol, S.; López, R.; Ramos, A.; Antelo, J.M.; Arce, F.; Anal. Chim. Acta 1999, 385, 443.

27. De Paolis, F.; Kukkonen, J.; Chemosphere 1997, 34, 1693.

28. Bard, A.J.; Faulkner, L.R.; Electrochem. Methods, Wiley: New York, 1980.

29. Macdonald, J.R.; Impedance Spectroscopy, Emphasizing Solid Materials and Systems, Wiley: New York, 1987.

Received: March 29, 2004

Published on the web: November 18, 2004

FAPESP helped in meeting the publication costs of this article. 